\title{
PEMBELAJARAN KOOPERATIF TIPE JIGSAW UNTUK MENINGKATKAN HASIL BELAJAR MATEMATIKA TENTANG MATERI HIMPUNAN KELAS X SMA NEGERI 9 BULUKUMBA
}

\author{
Gustina $^{1}$ \\ SMA Negeri 9 Bulukumba, Sulawesi Selatan, Indonesia
}

\begin{abstract}
ABSTRAK
Penelitian ini bertujuan Untuk mengetahui gambaran proses pembelajaran siswa sebelum penerapan model pembelajaran Kooperatif Tipe Jigsaw, Untuk mengetahui hasil aktivitas belajar siswa dengan menggunakan model pembelajaran kooperatif tipe jigsaw pada materi Himpunan dan untuk mengetahui apakah kooperatif tipe jigsaw dapat meningkatkan aktivitas pendidik dalam proses belajar mengajar di kelas. Jenis penelitian yang digunakan dalam penelitian ini adalah Penelitian Tindakan Kelas(PTK) atau classroom action research. Subjek dalam penelitian ini adalah siswa kelas $X$ yang berjumlah sebanyak 25 siswa,terdiri dari 10 siswa laki-laki dan 15 siswa perempuan. Instrument yang diguanakan dalam penelitian ini adalah angket, test, LKS, dan lembar observasi.Adapun teknik analisis data dalam penelitian ini adalah Analisis secara kualitatif artinya data yang di peroleh dari pelaksanaan observasi akan di analisis secara kualitatif. Berdasarkan pembahasan hasil penelitian yang telah disajikan, maka disimpulkan bahwa (1) Gambaran proses pemblajaran siswa sebelum penerapan model pembelajaran kooperatif tipe jigsaw adalah menggunakan metode ceramah sehingga kurang melibatkan peserta didik secara aktif dalam pembelajaran dan kurang aktif dalam berdiskusi, sehingga peserta didik didik merasa bosan karena selalu metode ceramah yang di ajarkan disaat proses belajar mengajar berlangsung, maka perlu diadakan perubahan metode belajarnya yaitu dengan menerapkan kooperatif tipe jigsaw. (2) Model pembelajaran kooperatif jigsaw dapat meningkatkan aktivitas peserta didik pada materi Himpunan pada peserta didik kelas X SMA Negeri 9 Bulukumba, dan (3) Dengan penerapan model pembelajaran kooperatif jigsaw dapat meningkatkan hasil belajar pada materi Himpunan pada peserta didik kelas X SMA Negeri 9 Bulukumba.
\end{abstract}

Kata kunci: Pembelajaran kooperatif, Jigsaw, Hasil Belajar, Matematika, Materi Himpunan

\section{PENDAHULUAN}

Dunia Pendidikan merupakan salah satu bidang dalam kehidupan yang sangat penting dan bermanfaat. Melalui pendidikan siswa dapat memperoleh pengetahuan yang dapat menunjang dan menyelesaikan berbagai permasalahan yang di hadapinya.

Pendidikan mempunyai peranan yang sangat besar dalam membentuk karakter, perkembangan ilmu dan mental seorang peserta didik yang nantinya akan diharapkan tumbuh menjadi seorang peserta didik yang nantinya akan diharapkan tumbuh menjadi seseorang manusia dewasa yang akan berinteraksi dan melakukan banyak hal terhadap lingkungan,baik secara individu maupun sebagai makhluk sosial.

Konsep pendiidkan tersebut terasa semakin penting ketika seseorang harus memasuki kehidupan di masyarakat dan dunia kerja,karena yang bersangkutan harus mampu menerapkan apa yang dipelajari disekolah untuk menghadapi masalah dalam kehidupan sehari-hari saat ini maupun yang 
akan datang.Secara umum pendidikan merupakan suatu sistem yang memiliki kegiatan yang cukup kompleks,meliputi berbagai komponen yang berkaitan satu sama lain.Jika menginginkan pendidikan terlaksana secara teratur ,berbagai komponen yang terlihat di dalam kegiatan pendidik.

Berikut beberapa tujuan pendidikan yang dikemukakan oleh Hamalik (2011:3-6) adalah:

a. Tujuan Pendidikan Nasional,tujuan yang hendak dicapai dalam sistem pendidikan nasional yang kapan saja biasa berubah sesuai dengan perkembangannya.

b. Tujuan Institusional,Tujuan yang hendak dicapai oleh suatu lembaga pendidikan atau suatu pendidikan tertentu.

c. Tujuan Kurikulum ,tujuan yang hendak dicapai oleh suatu program studi, bidang studi dan suatu mata ajaran yang disusun berdasarkan tujuan institusional.

d. Tujuan Pembelajaran (Instruksional), tujuan yang hendak dicapai setelah selesai diselenggarakan suatu proses pembelajaran misalanya acara pertemuan yang membahas perubahan tingkah laku siswa.

Peningkatan hasil belajar siswa juga selalu dipengaruhi oleh banyaknya faktor salah satunya ialah penggunaan model pembelajaran, seorang guru dapat menerapkan salah satu model pembelajaran inovatif yang membantu guru dan siswa dalam meningkatkan hasil belajar. Menurut Soetopo dalam Jalil (2005:51) bahwa Model pembelajaran adalah "kerangka konseptual yang melukiskan prosedur sistematis dalam mengorganisasikan pengalaman belajar untuk mencapai tujuan belajar tertentu."

Seorang guru di tuntut memilih model pembelajaran yang tepat untuk diterapkan dalam proses pembelajaran. Hal ini sangat penting untuk menciptakan suasana pembelajaran yang aktif, kondusif, dan menyenangkan. Cara guru melakukan suatu kegiatan pembelajaran memerlukan model berbeda dengan pembelajaran lainnya. Di dalam penggunaan model pembelajaran guru perlu memahami masalah agar dapat melaksankan pembelajaran secara efektif dalam meningkatkan hasil pembelajaran. Agar tujuan pembelajaran dapat dicapai, maka perlu dikembangkan model pembelajaran yang menarik dan menyenangkan untuk dapat menumbuhkan rasa percaya diri (optimis) dalam mencapai tujuan yang telah dirumuskan.

Sebagian besar peserta didik tidak atau kurang berminat terhadap pelajaran Matematika yang akhirnya berimplikasi pada rendahnya hasil belajar ekonomi mereka.Seiring dengan rendahnya hasil belajar peseeta didik dikarenakan model atau metode yang digunakan pendidik masih cenderung klasikal, melihat fenomena tersebut, maka salah satu usaha yang dilakukan untuk mengatasinya ialah dengan menggunakan model pembelajaran yang lebih efektif serta membuat peserta didik berpartisipasi aktif.Situasi kelas harus dirancang agar bisa membuat peserta didik termotivasi untuk mengikuti proses belajar mengajar agar hasil belajar peserta didik meningkat.

Permasalahan pembelajaran yang diungkapkan tersebut terjadi pada siswa SMA Negeri 9 Bulukumba,masih banyak siswa yang kurang aktif dalam kegiatan pembelajaran khususnya di kelas $\mathrm{X}$ mata pelajaran Matematika .Jika guru memberikan kesempatan kepada siswa untuk menyampaikan pendapatnya atau kesempatan untuk bertanya tentang materi pelajaran Matematika masih banyak siswa yang malas. Pengalamanyapun dalam membawakan forum diskusi masih belum baik, siswa juga masih terbiasa dengan kebiasaan menghapal materi-materi Matematika yang ada di buku siswa jarang dilatih dalam memecahkan masalah, dan saat diberi tugas siswa lebih 
cenderung menunggu jawaban temannya kemudian di contek. Fakta tersebut mengakibatkan proses belajar Matematika siswa dan keterampilan berfikir kreatif belum optimal.

Model pembelajaran kooperatif merupakan model pembelajaran yang digunakan dan menjadi perhatian serta dianjurkan oleh para ahli.Hal ini

Dikarenakan berdasarkan hasil penelitian yang dilakukan oleh slavin dalam Rusman ( 2012:205) dinyatakan bahwa:

penggunaan pembelajaran kooperatif dapat meningkatkan prestasi belajar dan sekaligus dapat meningkatkan hubungan sosial, menumbuhkan sikap toleransi, dan menghargai pendapat orang lain, (2) pembelajaran kooperatif dapat memenuhi kebutuhan siswa dalam berpikir kritis, memecahkan masalah, dan mengintegrasikan pengetahuan dan pengalaman.

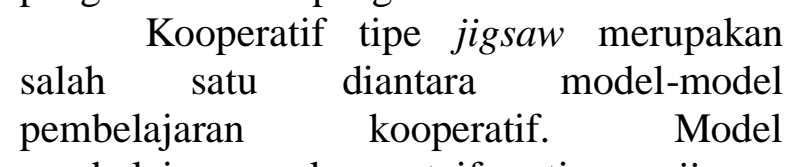
pembelajaran koopertaif tipe jigsaw membantu meningkatan kemampuan peserta didik dalam berdiskusi.Penggunaan model pembelajaran ini dapat meningkatkan proses belajar peserta diidk dalam pembelajaran yang pada gilirannya dapat meningkatkan hasil belajar peserta didik dalam proses belajar mengajar, model pembelajaran jigsaw diterapkan dalam dua kelompok yaitu kelompok asal dan kelompok ahli.

Berdasarkan uraian di atas mengenai pembelajaran kooperatif tipe jigsaw dapat disimpulkan bahwa model pembelajaran kooperatif dimana siswa belajar dalam kelompok kecil yang terdiri dari $4-6$ orang secara heterogen dan bekerja sama saling ketergantungan yang positif dan bertanggung jawab atas ketuntasan bagian materi pelajaran yang harus dipelajari dan menyampaikan materi tersebut kepada anggota kelompok yang lain.
Model pembelajaran berdasarkan masalah pada dasarnya lebih mendorong siswa untuk lebih aktif dalam memperoleh pengetahuan denganaktivitas yang dilakukan oleh siswa, diharapkan dapat menimbulkan rasa senang dan semangat dalam belajar.

\section{KAJIAN PUSTAKA}

\section{Pembelajaran Kooperatif}

Pembelajaran kooperatif merupakan model pembelajaran yang mengutamakan kerjasama diantara peserta didik untuk mencapai tujuan pembelajaran yang mengutamakan kerjasama diantara peserta didik untuk mencapai tujuan pembelajaran .

\section{Pengertian Pembelajaran Kooperatif}

Nurulhayati dalam Rusman (2013:203) menyatakan bahwa "Pembelajaran kooperatif adalah Strategi pembelajaran yang melibatkan partisipasi sisiwa dalam satu kelompok kecil untuk saling berinteraksi." Menurut Sanjaya dalam Rusman (2013:203), Pembelajaran kooperatif adalah Kegiatan belajar siswa yang dilakukan dengan cara berkelompok.Model pembelajaran kelompok adalah rangkaian kegiatan belajar yang dilakukan oleh siswa dalam kelompokkolompok tertentu untuk mencapai tujuan pembelajaran yang telah dirumuskan.

Menurut Dian Sukmawati dalam Jalil(2005:51),'Pembelajaran kooperatif adalah cara /teknik penyajian yang digunakan guru dalam proses pembelajaran agar tercapai tujuan pembelajaran."

Berdasarkan uraian di atas mengenai pembelajaran kooperatif dapat disimpulkan bahwa pembelajaran kooperatif adalah kerangka konseptual yang melukiskan prosedur sistematik dalam mengorganisasikan pengalaman belajar untuk mencapai tujuan belajar tertentu dan berfungsi sebagai pedoman bagiperancang pembelajaran dan para guru dalam merancang dan melaksanakan pembelajaran. Selanjutnya akan dijelaskan mengenai Karakteristik dari pembelajaran kooperatif. 
b. Tujuan Pembelajaran kooperatif

Menurut Sanjaya (dalam Rusman, 2013:209) menjelaskan bahwa tujuan pembelajaran kooperatif yaitu :

a. Hasil belajar akademik, yaitu unutuk meningkatkan kinerja peserta didik dalam tugas akademik.Pembelajaran model ini dianggap unggul dalam membantu peserta didik untuk memahami konsep- konsep yang sulit.

b. Penerimaan terhadap keragaman, yaitu agar peserta didik menerima teman-temannya yang mempunyai berbagai macam latar belakang.

c. Pengembangan keterampilan sosial, yaitu untuk mengembangankan keterampilan sosial peserta didik diantarannya : berbagai tugas, katif bertanya , menghargai pendapat orang lain, memancing teman untuk bertanya, mau mengungkapkan ide, dan bekerja dalam kelompok.

Menurut Tsaniah dalam Nurdiansah (2008 : 105) bahwa Struktur tujuan kooperatif terjadi jika siswa dapat mencapai tujuan mereka hanya jika siswa lain dengan siapa mereka bekerja sama mencapai tujuan tersebut. Tujuan-tujuan pembelajaran ini mencakup tiga jenis tujuan penting, yaitu hasil belajar akademik, penerimaan terhadap keragaman, dan pengembangan keterampilan sosial.

Berdasarkan penjelasan-penjelasan diatas mengenai tujuan pembelajaran kooperatif maka dapat disimpulkan bahwa tujuan pembelajaran kooperatif adalah meningkatkan partisipasi siswa, memfasilitasi siswa dengan pengalaman sikap kepemimpinan untuk membuat keputusan kelompok serta membantu siswa untuk saling bekerjasama dan saling menerima antara siswa yang memiliki kemampuan tinggi dan siswa yang memiliki kemampuan rendah.Selanjutnya penjelasan keunggulan dan kelemahan dari pembelajaran kooperatif.

Fakultas Keguruan dan Imu Pendidikan Universitas Bosowa Makassar

\section{c. Keunggulan dan Kelemahan Pembelajaran Kooperatif}

Dari beberapa penjelasan mengenai pembelajaran kooperatif terdapat beberapa keunggulan dan kelemahan yang disebutkan oleh beberapa ahli yaitu, Hasil penelitian melalui metode meta-analisis yang dilakukan oleh Johnson dan Johnson 1984 (dalam Kunandar 2013:150), menunjukkan adanya berbagai keunggulan pembelajaran kooperatif, yakni:

1. Memudahkan siswa melakukan penyesuaian sosial;

2. Mengembangkan kegembiraan belajar yang sejati;

3. Memungkinkan para siswa saling belajar mengenali sikap,

keterampilan, informasi, perilaku sosial, dan pandangan;

4. Memungkinkan terbentuk dan berkembangnya nilai-nilai sosial dan komitmen;

5. Meningkatkan kepekaan dan kesetiakawanan sosial.

Sanjaya (2012:249-250) mengemukakan keunggulan dari pembelajaran kooperatif adalah:

1. Melalui pembelajaran kooperatif siswa tidak terlalu menggantungkan pada guru, akan tetapi dapat menambah kepercayaan kemampuan berpikir sendiri, menemukan informasi dari berbagai sumber, dan belajar dari siswa lain.

2. Strategi pembelajaran kooperatif adalah dapat mengembangkan kemampuan mengungkapkan ide atau gagasan dengan kata-kata secara verbal dan membandingkannya dengan ide-ide orang lain.

3. Strategi pembelajaran kooperatif membantu anak untuk respek pada orang lain dan menyadari akan segala keterbatasannya serta menerima segala perbedaan.

4. Strategi pembelajaran kooperatif dapat membantu memberdayakan 
setiap siswa untuk lebih bertanggung jawab dalam belajar.

Sanjaya (2012: 250-251) menjelaskan berbagai kelemahan pembelajaran kooperatif adalah

1. Untuk memahami dan mengerti filosofis Strategi pembelajaran kooperatif memang butuh waktu. Sangat tidak rasional kalau kita mengharapkan secara otomatis siswa dapat mengerti dan memahami filsafat cooperative learning. Untuk siswa yang dianggap memiliki kelebihan, contohnya mereka akan merasa terhambat oleh siswa yang dianggap kurang memiliki kemampuan. Akibatnya, keaadaan semacam ini dapat mengganggu iklim kerja sama dalam kelompok.

2. Ciri utama dari Strategi pembelajaran kooperatif adalah bahwa siswa saling membelajarkan. Oleh karena itu, jika tanpa peer teaching yang efektif, maka dibangdingkan dengan pengajaran langsung dari guru, bisa terjadi cara belajar yang demikian apa yang seharusnya dipelajari dan dipahami tidak pernah dicapai oleh siswa.

3. Penilaian yang diberikan dalam Strategi pembelajaran kooperatif didasarkan dalam hasil kerja kelompok. Namun demikian, guru perlu menyadari, bahwa sebenarnya hasil atau prestasi yang diharapkan adalah prestasi setiap individu siswa.

Berdasarkan beberapa uraian tentang kelebihan dan kelemahan model pembelajaran kooperatif, maka dapat disimpulkan bahwa:

a. Kelebihan Model Pembelajaran Kooperatif

1. Meningkatkan motivasi belajar siswa

2. Mengembangkan kemampuan siswa untuk saling bekerjasama dalam kelompok.
3. Belajar saling menerima kelebihan serta kekurangan setp individu

4. Membantu setiap siswa untuk tidak takut memunculkan ide-ide baru mereka.

5. Menghilangkan rasa bosan

b. Kekurangan Model Pembelajaran Kooperatif

1. Siswa yang memiliki kemampuan tinggi akan mendominasi jalannya diskusi sehingga siswa yang kemampuannya rendah menjadi minder, artinya mereka malu untuk menyampaikan pendapatnya.

2. Membutuhkan waktu yang banyak jika mengatur tempat duduk setiap kelompok.

3. Siswa yang lain dapat menyalin pekerjaan siswa yang pandai tanpa memiliki pemahaman yang memadai.

\section{Pengertian Hasil Belajar Matematika a. Pengertian Hasil Belajar}

Hasil belajar memiliki peran penting dalam proses pembelajaran.Penilaian hasil belajar dapat memberikan informasi kepada pendididk tentang kemajauan .berbagai kegiatan belajar. Selanjutnya , dari informasi tersebut pendiidk dapat menyusun dan membina kegiatan - kegiatan peserta didik lebih lanjut, baik buruk keseluruhan kelas maupun individu.

Menurut Juliah dalam Jihad (2013:15), hasil belajar adalah "segala sesuatu menjadi milik siswa sebagai akibat dari kegiatan belajar yang dilakukannya."

Menurut Tsaniah dalam Nurdiansah ( 2008 :27) bahwa Hasil belajar adalah terjadinya perubahan tingkah laku pada diri peserta didik, yang dapat diamati dan diukur dalam bentuk perubahan pengetahuan, sikap, dan keterampilan .Perubahan tersebut dapat diartikan terjadinya peningkatan dan pengembangan yang lebih baik dibandingkan dengan sebelumnya, misalnya tidak tahu , sikap kurang sopan menjadi sopan, dan sebagianya. 
Berdasarkan uraian di atas mengenai belajar dapat disimpulkan bahwa pengertian hasil belajar merupakan hasil yang akan dicapai dari pengalaman belajar.Dalam setiap kegiatan yang dilakukan manusia selalu berusaha untuk

Mencapai keberhasilan.Begitu pula dalam kegiatan belajar mengajar di sekolah, seseorang peserta didik melakukan kegiatan belajar selalu menginginkan keberhasilan didalam belajarnya. Dalam dunia pendidikan keberhasilan belajar disebut belajar.

Tipe hasil belajar lebih dominan daripada afektif dan psikomotor karena lebih menonjol, namun hasil belajar psikomotor dan afektif juga harus menjadi bagian dari hasil penilaiaan dalam proses pembelajaran di sekolah.

Menurut Deliarnov (2003 : 3), "Matematika adalah semua kegiatan yang khusus mempelajari tingkah laku manusia atau golongan masyarakat dalam usahaanya memenuhi kebutuhan yang relatif terbatas adanya."

Nurhadi dalam Deliarnov (2003: 20 ) menyatakan bahwa "Matematika adalah semua kegiatan manusia untuk memenuhi kebutuhan dengan memanfaatkan segala sumber daya yang ada."

Dari pengertian di atas dapat disimpulkan bahwa Matematika adalah ilmu tentang upaya manusia untuk memenuhi kebutuhan hidupnya.

Dari definisi para ahli diatas maka pengertian hasil belajar Matematika adalah hasil akhir yang dicapai peserta didik melalui pengukuran keterampilan , pengetahuan dan kemajuan belajar Matematika dalam waktu tertentu.

\section{Pembelajaran Kooperatif tipe jigsaw a. Pengertian Jigsaw}

Menurut Lie dalam Rusman (2013:218) pembelajaran kooperatif tipe jigsaw adalah “ Sebuah model belajar kooperatif yang menitiberatkan pada kerja kelompok siswa dalam bentuk kelompok kecil.”
MenurutJhonson dalam Rusman (2013:218)pembelajaran kooperatif tipe jigsaw adalah "suatu teknik mengkondisikan siswa untuk beraktifitas secara kooperatif dalam dua kelompok,yaitu kelompok asal dan kelompok ahli."

Pada pembelajaran tipe jigsaw ini setiap siswa menjadi anggota dari2 kelompok, yaitu anggota kelompok asal dan anggota kelompok ahli.Anggota kelompok asal terdiri dari 3-5 siswa yang setiap anggotanya diberi nomor kepala 1-5.Nomor kepala yang sama pada kelompok asal berkumpul pada suatu kelompok yang disebut kelompok ahli. Kooperatif tipe jigsaw didesain untuk meningkatkan rasa tanggung jawab siswa terhadap pembelajarannya sendiri dan juga pembelajaran orang lain, tetapi mereka juga harus siap memberikan dan mengajarkan materi tersebut pada anggota kelompoknya yang lain. Dengan demikian, siswa saling tergantung satu dengan yang lain dan harus bekerja sama secara kooperatif untuk mempejari materi yang ditugaskan.

Berdasarkan uraian di atas mengenai pembelajaran kooperatif tipe jigsaw dapat disimpulkan bahwa model pembelajaran kooperatif dimana siswa belajar dalam kelompok kecil yang terdiri dari $4-6$ orang secara heterogen dan bekerja sama saling ketergantungan yang positif dan bertanggung jawab atas ketuntasan bagian materi pelajaran yang harus dipelajari dan menyampaikan materi tersebut kepada anggota kelompok yang lain.

Setiap model pembelajaran pasti memiliki kelebihan dan kelemahan masingmasing. Begitu pun dengan model pembelajarn kooperatif tipe jigswa berikut merupakam beberapa kelebihan dan kekurangan dari model pembelajaran kooperatif tipe Jigsaw.
b. Kelebihan
dan
Kelemahan
Pembelajaran Kooperatif jigsaw
Menurut Lie dalam Rusman (2013:219) ada beberapa kelebihan dan kelemahan. 
Kelebihan Pembelajaran Kooperatif Jigsawadalah:

1. Meningkatkan rasa tanggung jawab siswa terhadap pembelajarannya sendiri dan juga pembelajaran orang lain.

2. Siswa tidak hanya mempelajari materi yang diberikan, tetapi mereka juga harus siap memberikan dan mengerjakan materi tersebut pada anggota kelompoknya yang lain, sehingga pengetahuannya jadi bertambah.

3. Menerima keragaman dan menjalin hubungan sosial yang baik dalam hubungan dengan belajar

4. Meningkatkan berkerja sama secara kooperatif untuk mempelajari materi yang ditugaskan.

Adapun yang menjadi kelemahan dari model pembelajaran ini adalah

1. Jika guru tidak mengingatkan agar siswa selalu menggunakan keterampilan-keterampilan kooperatif dalam kelompok masing-masing maka dikhawatirkan kelompok akan macet dalam pelaksanaan diskusi.

2. Jika anggota kelompoknya kurang akan menimbulkan masalah.

3. Membutuhkan waktu yang lebih lama, apalagi bila penataan ruang belum terkondisi dengan baik sehingga perlu waktu untuk merubah posisi yang dapat menimbulkan kegaduhan.

Menurut Ibrahim dalam Rusman ( 2013 : 225) bahwa belajar kooperatif dapat mengembangkan tingkah laku kooperatif dan hubungan yang lebih baik antar siswa, dan dapat mengembangkan kemampuan akademis siswa.Sedangkan kelemahannya adalah Prinsip utama pola pembelajaran ini adalah "peer teaching " pembelajaran oleh teman sendiri, akan menjadi kendala karena perbedaaan persepsi dalam memahami suatu konsep yang akan didiskusikan bersama dengan siswa lain.

Fakultas Keguruan dan Imu Pendidikan Universitas Bosowa Makassar
Dari pengertian diatas dapat disimpulkan bahwa kelebihan tipe jigsaw adalah dapat mengembangkan kemampuan akademis siswa dan kelemahannya adalah Prinsip utama pola pembelajaran ini adalah "peer teaching " pembelajaran oleh teman sendiri, akan menjadi kendala karena perbedaaan persepsi dalam memahami suatu konsep yang akan didiskusikan bersama dengan siswa lain.Selanjutnya penjelasan langkah-langkah dari kooperatif tipe jigsaw.

c. Langkah Langkah Penerapan Model Pembelajaran Teknik Jigsaw

Menurut Step dalam Rusman (2013:219) langkah-langkah pembelajaran kooperatif tipe jigsaw sebagai berikut :

1. Guru membagi suatu kelas menjadi beberapa kelompok,dimanaanggota kelompok terdiri dari 4-6 siswa dengan kemampuan yang berbedabeda.Kelompok ini disebut kelompok asal.Jumlah anggota dalam kelompok asal menyesuaikan dengan jumlah bagian materi pelajaran yang akan dipelajari siswa sesuai dengan tujuan pembelajaran yang akan dicapai.Dalam tipe jigsaw ini,setiap siswa diberi tugas mempelajari satu bagian materi dalam pelajaran tersebut.Semua siswa yang materinya sama akan belajar bersama dan membentuk kelompok baru yang disebut dengan kelompok ahli.Dalam kelompok ahli,siswa mendiskusikan bagian materi pembelajaran yang sama,serta menyusun rencana bagaimana cara menjelaskan atau menyampaikan pada temanya jika kembali ke anggota kelompok asal,karena setiap anggota kelompok ahlI mempunyai tanggung jawab untuk kembali kepada klompok asalnya untuk memberikan informasi hasil belajar yang telah diperoleh atau dipelajari dalam kelompok ahli.

2. Setiap siswa berdiskusi dalam kelompok ahli maupun kelompok asal,selanjutnya dilakukan persentasi masing-masing kelompok,atau dilakukan pengundian 
salah satu kelompok untuk menyajikan hasil diskusi kelompoknya yang telah dialkukan agar guru dapat menyamakan persepsi pada materi pembelajaran yang telah didiskusikan.

3. Guru memberikan kuis untuk siswa secara individual.

4. Guru memberikan penghargaan pada kelompok dengan memberikan skor penghargaan berdasarkan perolehan nilai dari peningkatan hasil belajar individual dari skor dasar ke skor kuis berikutnya.

5. Materi sebaiknya dibagi secara alami menjadi beberapa bagian pada tiap -tiap anggota kelompoknya.

6. Perlu diperhatikan bahwa jika menggunakan jigsaw untuk belajar materi baru,maka perlu dipersiapkan suatu tuntunan dari isi materi yang runtut serta waktu yang cukup sehingga tujuan pembelajaran dapat tercapai.

Dengan model pembelajaran kooperatif tipe jigsaw ini, diharapkan bisa membuat peserta didik bersemangat dan beraktivitas tinggi dalam belajar.Di dalam kooperatif tipe jigsaw ini mengandung suatu unsur kerjasama dalam kelompok yang membantu peserta didik berperan aktif dalam pembelajaran bukan pendidik.Para siswa tersebut diberikan tugas untuk membaca beberapa bab atau unit, dan diberikan lembar ahli yang terdiri atas topik-topik yang berbeda yang harus menjadi fokus perhatian masing-masing anggota tim saat mereka membaca.Dengan kooperatif tipe jigsaw tanggung jawab individu sekaligus tanggung jawab kelompok, sehingga dalam diri siswa terbentuk sikap ketergantungan positif yang menjadikan kerja kelompok optimal.Keadaan ini mendukung siswa dalam kelompoknya belajar bekerja sama dan tanggung jawab dengan sungguh-sungguh sampai suksesnya tugas-tugas dalam kelompok.

Fakultas Keguruan dan Imu Pendidikan Universitas Bosowa Makassar

\section{Universitas Bosowa Makassar}

\section{Keterkaitan Model Pembelajaran Kooperatif Tipe Jigsaw Dengan Peningkatan Hasil Belajar}

Model pembelajaran kooperatif sangat berbeda dengan model pembelajaran langsung.Disamping model pembelajaran kooperatif dikembangkan untuk mengembangkan kerjasama antar peserta didik, pembelajaran kooperatif juga efektif untuk mencapai hasil belajar akademik peserta didik. Beberapa para ahli diatas berpendapat bahwa model kooperatif tipe jigsaw ini unggul dalam membantu peserta didik memahami konsep-konsep yang sulit melalui proses belajar secara heterogen. Para pengembang model kooperatif tipe jigsaw telah menunjukan bahwa model kooperatif tipe jigsaw telah dapat meningkatkan hasil belajar peserta didik dan perubahan sikap peserta didik yang berhubungan dengan hasil belajar, pembelajaran kooperatif dapat memberikan keuntungan baik pada peserta didik yang berkemampuan tinggi maupun peserta didik yang berkemampuan rendah atas kerjasama dalam menyelesaikan tugastugas yang diberikan oleh pendidik.

\section{METODE PENELITIAN}

Jenis penelitian yang digunakan dalam penelitian ini adalah Penelitian Tindakan Kelas(PTK) atau classroom action research,objek penelitian ini adalah sekolah yang pelaksanaanya dari awal sampi akhir penelitian.Menganalisis keadaan secara langsung proses belajar mengajar terutama dalam mata pelajaran Matematika serta model pembelajaran yang digunakan oleh guru bidang studi.

Dalam penelitian tindakan kelas ini peneliti akan berkolaborasi dengan guru sehingga peneliti lebih mudah memahami kondisi peserta didik serta berpartisipasi aktif dan terlibat langsung dalam prosese penelitian danmemberikan gambaran atau kerangka kerja secara sistematis tentang keeefektian model pembelajaran kooperatif 
tipe jigsaw baik kepada guru bidang studi yang bersangkutan maupun peserta didik.

Subjek dalam penelitian ini adalah siswa kelas $\mathrm{X}$ yang berjumlah sebanyak 25 siswa,terdiri dari 10 siswa laki-laki dan 15 siswa perempuan.

Untuk mendapatkan instrumen yang valid maka peneliti menyesuaikan soal-soal dengan materi yang akan dibahas. Berdasarkan hasil uji validitas di atas yang sudah dilakukan bahwa frekuensi dari uji validitas dapat diuraikan sebagai berikut:

a. Angket untuk memperoleh data tentang tanggapan peserta didik tentang penerapan model pembelajaran tipe jigsaw dengan 10 jumlah item pertanyaan.Berdasarkan penilaian pada lembar validasi angket, maka diperoleh presentase penilaiannya yaitu 82,5 persen dengan penilaian validasi valid dapat digunakan dengan revisi kecil.

b. Tes/Evaluasi,untuk memperoleh data tentang hasil belajar peserta didik sebelum dan setelah diterapkan Kooperatif Tipe Jigsaw .Tes atau evaluasi pre tes dan post tes pada siklus I dan Siklus II yang terdiri dari 5 butir soal,sedangkan pada siklus II yang terdiri dari 5 butir soal.Berdasarkan penilaian pada lembar validasi tes hasil belajar,adapun persentase penilainya yaitu 83,6 persen dengan penilaian umum yaitu valid untuk digunakan dengan revisi kecil.

c. Lembar Kegiatan siswa (LKS), sebagai lembar kerja yang berisikan soal/masalah yang berkaitan dengan materi pelajaran yang digunakan untuk mengembangkan kemampuan berpikir peserta didik dalam menyelesaikan masalah yang diselesaikan secara kelompok.Berdasarkan penilaian pada lembar validasi LKS,adapun persentase penilaianya yaitu 84 persen dengan penilaian umum yaitu dapat digunakan revisi kecil. d. Lembar Observasi,untuk memperoleh data tentang kondisi pelaksaan Kooperatif Tipe Jigsaw di kelas.Lembar observasi untuk peserta didik adapun persentase penilaiannya 86,6 persen dapat digunakan dengan revisi kecil.

e. Rencana Pelaksanaan Pembelajaran (RPP),sebagi pedoman pelaksanaan pembelajaran dengan penerapan Kooperatif Tipe Jigsaw.Berdasarkan penilaian pada lembar validitas rencana pelaksanaan pembelajaran (Lampiran 1).Adapun persentase penilainya yaitu 83,52 persen dengan penilaian umum yakni dapat digunakan dengan revisi kecil.

Adapun teknik analisis data dalam penelitian ini adalah Analisis secara kualitatif artinya data yang di peroleh dari pelaksanaan observasi akan di analisis secara kualitatif

\section{HASIL PENELITIAN DAN PEMBAHASAN}

\section{Hasil Penelitian}

Pada hari rabu tanggal 04 Maret 2018 yang waktunya disesuaikan dengan roster mata pelajaran Matematika 09.00-11.30 Wita.Tes awal dikuti oleh 25 orang siswa dengan 2 orang siswa yang berketerangan izin.Dari 25 jumlah siswa tersebut terdiri dari 15 orang siswa perempuan dan 10 orang siswa laki-laki.Adapun tujuan dari tes awal ini adalah untuk melihat sejauh mana siswa menangkap atau memahami materi yang telah diberikan oleh guru selain itu sebagai perbandingan nantinya setelah mengikuti model pembelajaran yang akan diterapkan oleh peneliti yang bekerja sama (kolaborasi) dengan guru mata pelajaran Matematika.

Berdasarkan hasil pemberian tes awal yang menunjukan hasil belajar Matematika peserta kelas X SMP Negeri 9 Bulukumba, Sebelum pelaksanaan tindakan dengan menggunakan model pembelajaran kooperatif tipe jigsaw yang dapat dilihat pada lampiran, dan disajikan pada tabel dibawah ini. 
Tabel 1 Deskriptif Skor Hasil Belajar Matematika Peserta Didik Pada Pre Tes

\begin{tabular}{lll}
\hline No & Statistik & Nilai Statistik \\
\hline 1. & Subjek Penelitian & 25 \\
2. & Skor Ideal & 100 \\
3. & Skor Tertinggi & 75 \\
4. & Skor Terendah & 20 \\
5. & Skor Rata-rata & 50,8 \\
\hline \multicolumn{2}{l}{ Sumber : Olah data hasil belajar peserta didik } \\
Tes Awal, 2018
\end{tabular}

Berdasarkan tabel 1 menjelaskan bahwa skor rata-rata peserta didik masih rendah .Hal ini disebabkan karena belum ada pembahasan tentang materi Himpunan sehingga masih terlalu jauh untuk mencapai nilai ideal yaitu 100, maka dari itu penelitian ini perlu dilanjutkan ke siklus I. Selanjutnya diperoleh distribusi Frekuensi dan persentase skor hasil belajar Matematika peserta didik pada pre tes yang dilihat pada tabel 2 dibawah ini.

Tabel 2 Distribusi Frekuensi Dan Persentase Skor Hasil Belajar Peserta Didik kelas SMA Negeri 9 Bulukumba Pada Pre Tes

\begin{tabular}{lllc}
\hline Interval & & & \\
Nilai & Kategori & Frekuensi & Persentase \\
\hline $90-100$ & Sangat Tinggi & 0 & 0,00 \\
$80-85$ & Tinggi & 0 & 0,00 \\
$70-75$ & Cukup & 5 & 20 \\
$60-65$ & Rendah & 6 & 24 \\
& Sangat & & 56 \\
$0-55$ & Rendah & 14 & 100,00 \\
\hline Jumlah & & 31 & \\
\hline \multicolumn{2}{l}{ Sumber : Olah data hasil belajar peserta didik Tes } \\
Awal, 2018
\end{tabular}

Berdasarkan skor rata-rata hasil belajar peserta didik yang diperoleh sebelum proses belajar mengajar selama pre tes berlangsung terlihat masih banyak yang mendapat kategori nilai sangat rendah dan belum ada peserta didik yang mencapai kategori nilai sangat tinggi .Hal ini disebabkan karena belum ada pembahasan tentang materi Himpunan dan belum diterapkan model kooperatif tipe jigsaw.
Deskripsi secara kuantitatif ketuntasan belajar Matematika peserta didik setelah memberikan tindakan dapat dilihat pada tabel 3 dibawah ini.

Tabel 3 Deskriktif Ketuntasan Skor Hasil Tes Awal Peserta Didik Kelas X SMA Negeri 9 Bulukumba

\begin{tabular}{llll}
\hline Skor & Kategori & Frekuensi & Persentase \\
\hline $0-71$ & Tidak Tuntas & 20 & 88 \\
$75-100$ & Tuntas & 3 & 12 \\
\hline & Jumlah & 25 & 100,00 \\
\hline
\end{tabular}

Sumber : Olah data hasil belajar peserta didik Tes Awal, 2018

Berdasarkan pada tabel 3 dapat diketahui bahwa persentase ketuntasan belajar peserta didik sebelum pelaksanaan tindakan tegolong sangat rendah.Hal ini disebabkan karena belum ada pembahasan tentang materi Himpunan dan belum diterapkan model kooperatif tipe jigsaw.

\section{a. Data Tindakan Siklus I}

Pelaksanaan tindakan siklus 1 berlangsunng pada tanggal 19 Maret 2018 dengan lama waktu setiap pertemuan 3 x 45 menit.Pada pukul 09.00-11.30 Wita, (Sesuai dengan roster mata pelajaran). Dengan jumlah peserta didik kelas VII $_{4}$,yaitu 24 orang pada saat pelaksanaan tindakan siklus I ini 2 orang yang tidak sempat hadir dengan keterangan sakit.Sesuai dengan Nilai tes hasil belajar Matematika, setelah pelaksanan tindakan siklus 1 melalui penerapan model pembelajaran kooperatif tipe jigsawdapat dilihat pada tabel 4.4 deskriptif skor hasil belajar Matematika peserta didik pada siklus I berikut ini.

Tabel 4 Deskriptif Skor Hasil Belajar Matematika Peserta Didik Pada Siklus 1

\begin{tabular}{lll}
\hline No & Statistik & Nilai Statistik \\
\hline 1. & Subjek Penelitian & 25 \\
2. & Skor Ideal & 100 \\
3. & Skor Tertinggi & 90 \\
4. & Skor Terendah & 45 \\
5. & Skor Rata-rata & 71,8
\end{tabular}


Sumber : Olah data hasil belajar peserta didik Siklus I, 2018

Berdasarkan Tabel 4 menjelaskan bahwa skor rata-rata hasil belajar peserta didik masih rendah,ini membuktikan bahwa peserta didik kurang aktif dalam proses belajar sehingga tidak saling bertukar pendapat dan kurang menguasai materi yang diajarkan sehingga masih terlalu jauh untuk mencapai skor ideal yaitu 100 maka dari itu proses belajar peserta didik harus diperbaiki dan peserta diidk harus lebih giat dalam belajar sehingga mencapai nilai tertinggi.Maka dari itu penelitian ini perlu dilanjutkan ke siklus II.Selanjutnya diperoleh distribusi Frekuensi dan Persentase skor hasil belajar Matematika peserta didik pada siklus 1 yang dapat dilihat pada tabel 5 dibawah ini.

Tabel 5 Distribusi Frekuensi Dan Persentase Skor Hasil Belajar Peserta Didik kelas X SMA Negeri 9 Bulukumba Pada Siklus I

\begin{tabular}{llll}
\hline $\begin{array}{l}\text { Interval } \\
\text { nilai }\end{array}$ & Kategori & Frekuensi & Persentase \\
\hline $90-100$ & Sangat Tinggi & 2 & 8 \\
$80-85$ & Tinggi & 3 & 12 \\
$70-75$ & Cukup & 13 & 52 \\
$60-65$ & Rendah & 6 & 24 \\
$0-55$ & Sangat Rendah & 1 & 4 \\
\hline Jumlah & & 31 & 100,00
\end{tabular}

Sumber : Olah data hasil belajar peserta didik Siklus I, 2018

Berdasarkan skor rata-rata hasil belajar peserta didik yang diperoleh setelah proses belajar mengajar selama siklus I berlangsung sudah ada peningkatan hasil belajar walaupun masih ada beberapa peserta didik yang belum mencapai nilai KKM,ini disebabkan karena peserta didik kurang memperhatikan pada saat pembahasan materi diskusi kelompok berjalan dan kurang menguasai materi.

Deskripsi secara kuantitatif ketuntasan belajar Matematika peserta didik setelah memberikan tindakan dapat dilihat pada tabel 6 dibawah ini.
Tabel 6 Deskripsi Dan Persentase Skor Hasil Belajar Peserta Didik Kelas X SMA Negeri 9 Bulukumba Pada Siklus I

\begin{tabular}{llll}
\hline Skor & Kategori & Frekuensi & Persentase \\
\hline $0-74$ & Tidak Tuntas & 12 & 48 \\
$75-100$ & Tuntas & 13 & 52 \\
\hline & Jumlah & 25 & 100,00 \\
\hline
\end{tabular}

Sumber : Olah data hasil belajar peserta didik Siklus I, 2018

Berdasarkan pada tabel 6 dapat diketahui bahwa persentase ketuntasan belajar peserta didik pada siklus I sudah ada peningkatan hasil belajar walaupun masih ada beberapa peserta didik yang belum mencapai nilai KKM,ini disebabkan karena peserta didik kurang memperhatikan pada saat pembahasan materi diskusi kelompok berjalan, kurang menguasai materi dan tidak saling bertukar pendapat.Selanjutnya dibawah ini akan di bahas Proses Pelaksanan Tindakan Kelas Pada siklus I sebagai berikut.

\section{1.) Tahapan Perencanaan Siklus $I$}

Pada tahap perencanaan siklus I peneliti menelaah kurikulum dan materi pelajaran Matematika semester II Kelas X SMA Negeri 9 Bulukumba dan menemukan pokok pembahasan yang di ajarkan yaitu Himpunan. Hal tersebut dilakukan untuk dijadikan sebuah patokan dalam terhadap standar kompetensi yang ingin di capai pada mata pelajaran Matematika.

Setelah peneliti melakukan pengecekan atau kurikulum yang digunakan di SMA Negeri 9 Bulukumba maka peneliti selanjutnya membuat sebuah skenario pembelajaran yang meliputi,pembuatan rencana pelaksaan pembelajaran (RPP) ,pembuatan lembar kerja siswa (LKS),pembuat lembar observasi untuk mengetahui suasana proses belajar mengajar yang sedang berlangsung pada saat penerapan pembelajaraan Kooperatif Model Jigsaw pembuatan alat bantu mengajar yang diperlukan dalam rangka membantu siswa dalam memahami materi dengan baik,dan 
membuat alat evaluasi dalam bentuk tes untuk melihat tingkat penguasaan materi Matematika sistem himpunan.

\section{2.) Tahapan Pelaksaan Tindakan Siklus I}

Pelaksanaan tindakan siklus 1 berlangsunng pada tanggal 19 Maret 2018 dengan lama waktu setiap pertemuan $3 \times 45$ menit.Pada pukul 09.00-11.30 Wita,(Sesuai dengan roster mata pelajaran).Dengan jumlah peserta didik kelas $\mathrm{VII}_{4}$,yaitu 25 orang pada saat pelaksanaan tindakan siklus I ini 1 orang yang tidak sempat hadir dengan keterangan sakit.Sesuai dengan Nilai tes hasil belajar Matematika. Proses belajar mengajar dibagi dalam tiga tahapan kegiatan proses belajar mengajar yaitu : (a) Kegiatan awal , (b) Kegiatan Inti dan (c) kegiatan akhir.

a.) Kegiatan Awal

Adapun kegiatan awal yang dilakukan di kelas X SMA Negeri 9 Bulukumba sebelum memulai pelajaran maka ketua kelas menyiapkan temantemanya lalu berdoa sesuai dengan keyakinannya masing-masing, setelah itu pendidik lalu mengabsen siswa yang hadir satu persatu.Pendidik kemudian menjelaskan model pembelajaran Kooperatif Model Jigsaw , kemudian pendidik menginformasikan KD, Indikator dan tujuan pembelajaran kooperatif tipe jigsaw. Selain itu pendidik juga memberikan motivasi dan pendidik juga mengingatkan kembali materi yang telah di ajarkan sebelumnya yang berkaitan dengan materi yang diajarkan.

a.) Kegiatan Inti

Pada kegiatan inti proses pembelajaran , pendidik membagi suatu kelas menjadi beberapa kelompok, dengan setiap kelompok terdiri dari $4-6$ siswa secara berheterogen selanjutnya tiap tim di beri materi yang berbeda-beda Tiap orang dalam tim diberi bagian materi yang ditugaskan kemudian Anggota dari tim yang berbeda yang telah mempelajari bagian sub bab yang sama bertemu dalam kelompok baru (kelompok ahli) untuk mendiskusikan sub bab mereka. Setelah selesai diskusi sebagai tim ahli, tiap anggota kembali ke kelompok asal dan bergantian mengajar dan tiap anggota lainnya mendengarkan dengan sungguh-sungguh .Selanjutnya Tiap tim ahli mempresentasekan hasil diskusi .

b.) Kegiatan Akhir

Pada kegiatan akhir pelaksanaan pembelajaran pendidik dan peserta didik bersama-sama menyimpulkan pada materi yang telah dibahas.Dan pendidik mengingatkan kembali materi yang telah diajarkan dan pada materi selanjutnya .Selanjutnya pendidik menutup kegiatan pembelajaran dengan berdoa bersama dan memberi salam.

\section{1.) Hasil Observasi}

\section{a. Observasi}

Aktivitas peserta didik dalam pelaksanaan siklus I pertemuan pertama dan pertemuan ketiga selama proses belajar mengajar berlangsung dalam tindakan yang dilakukan dengan menggunakan lembar observasi aktivitas peserta didik dapat dilihat pada tabel 4.7 berikut ini.

Tabel 7 Perkembangan Aktivitas Peserta Didik Kelas X SMA Negeri 9 Bulukumba Pada Siklus

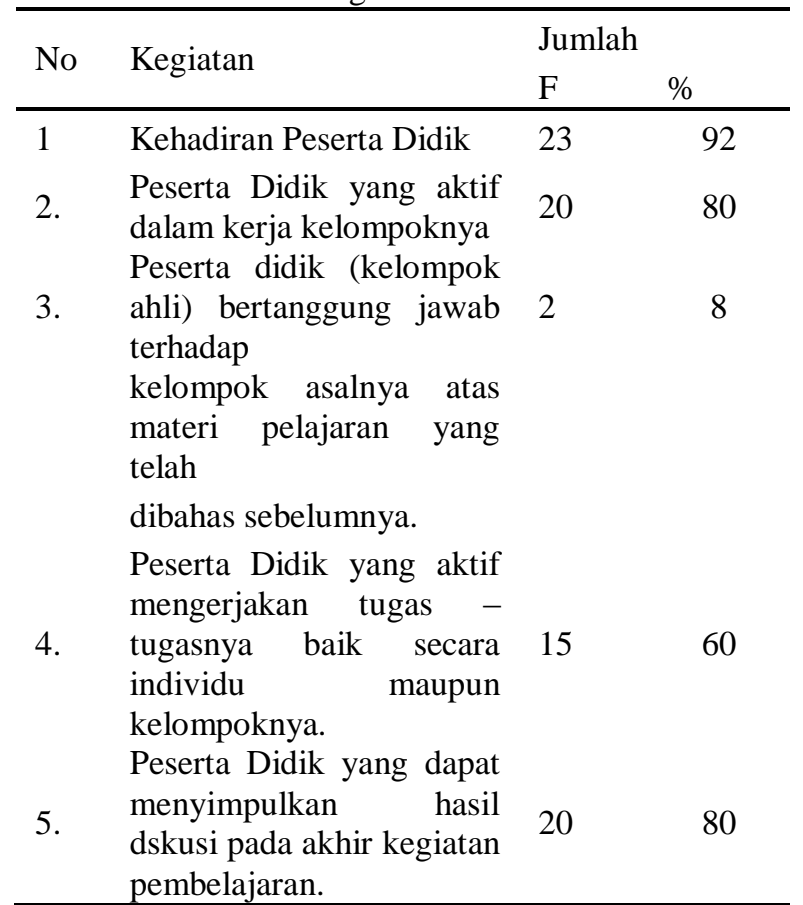

Sumber : Olah Data Aktivitas Peserta Didik Siklus I, 2018 
Berdasarkan tabel 7 terlihat bahwa aktivitas peserta didik pada siklus I hanya sebagian kecil yang mampu berperan secara aktif dalam proses belajar mengajar, ini membuktikan bahwa peserta didik harus diberikan pemahaman tentang pentingnya keaktifan dalam proses belajar mengajar sehingga mampu melakukan perannya dengan baik.Oleh karen itu penelitian ini harus dilanjutkan pada siklus II setelah dilakukan refleksi pada siklus I.

Tabel 8 Perkembangan Aktivitas Pendidik Dalam Pembelajaran Matematika pada Siklus I

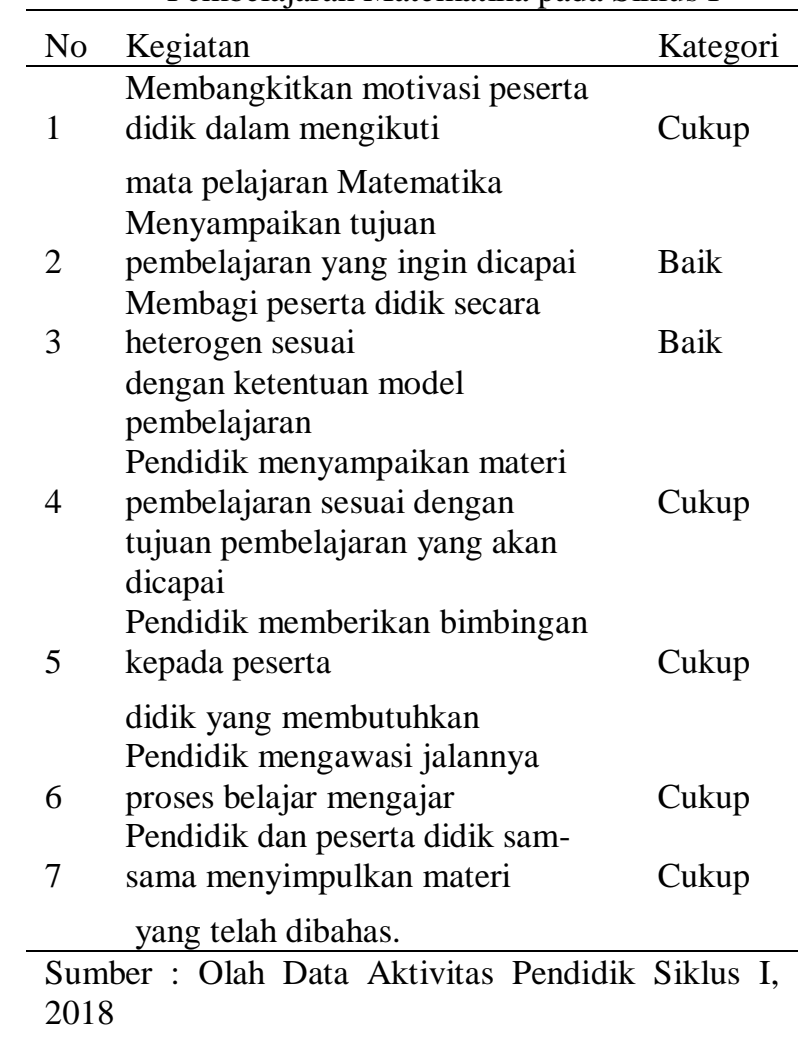

Berdasarkan tabel 8 diatas terlihat bahwa aktivitas pendidik siklus I masih dinilai cukup karena aktivitas pendidik dalam melaksankan pembelajaran belum sepenuhnya sesuai dengan perencanaan pembelajaran.Dari hasil observasi pengamat, hal ini terjadi karena peneliti masih canggung untuk berinteraksi secara intensif dengan peserta didik, dan peneliti pun belum dapat mengelola kelas dengan baik.

\section{4.) Tahap Refleksi Siklus I}

Setelah dilaksankan tindakan pembelajaran yang terdiri dari tiga kali pertemuan dalam siklus I, diman sebagain peserta didik sudah mulai memperlihatkan respon yang cukup baik dalam penggunaan model pembelajaran kooperatif tipe jigsaw dengan berperan secara aktif dalam mengikuti proses belajar mengajar di dalam kelas. Namun ada saja masalah dan hambatan yang masih nampak pada saat kegiatan pembelajaran berlangsung pada siklus I.

Berdasarkan hasil observasi dan peneliti selama pembelajaran maka diperoleh beberapa hal yang perlu diperhatikan oleh peneliti sehingga menjadi bahan perbaikan untuk siklus berikutnya :.

1. Pendidik belum mampu memperhatikan kendala-kendala yang dialami peserta didik dalam kelompoknya secara merata.

2. Tiap kelompok menunjukan kerjasama antar sesama anggota kelompok saat mengerjakan LKS yang diberikan oleh pendidik atau peneliti.

3. Masih ada beberapa peserta didik yang tidak mengerjakan tugas yang diberikan saat diskusi.

4. Masih kurangnya perhatian peserta didik pada saat proses pembelajaran.

5. Masih canggungnya peserta didik yang bertanya tentang materi yang tidak dipahami.

Dari hasil tindakan siklus I yang diberikan, peserta didik yang telah mencapai target sesuai dengan KKM sebanyak 13 orang dan 12 orang yang belum mencapai nilai KKM.Berdasarkan analisis diatas maka pendidik dan peneliti memutuskan untuk melanjutkan pada tindakan siklus II dengan proses yang hampir sama dengan siklus I.

\section{c.) Data Tindakan Siklus II}

Pelaksanaan tindakan siklus II berlangsung 3 kali pertemuan dengan lama waktu setiap pertemuan yaitu 3 X 45 menit yang dilaksanakan pada hari kamis tanggal 16 April sesuai dengan roster mata pelajaran,pada saat pertemuan pertama di 
siklus II di hadiri 25 peserta didik dari jumlah keseluruhan jumlah peserta didik 25 orang.Adapun Nilai tes hasil belajar Matematika kompetensi dasar Mendeskripsiakan Pengertian Manajemen,peserta didik kelas X SMA Negeri 9 Bulukumba,setelah pelaksanaan tindakan siklus II melalui penerapan model pembelajaran kooperatif tipe jigsaw dapat dilihat pada tabel di bawah ini.

Tabel 9 Deskriptif Skor Hasil Belajar Matematika Peserta Didik Pada Siklus II

\begin{tabular}{|c|c|c|}
\hline No & Statistik & Nilai Statistik \\
\hline 1. & $\begin{array}{l}\text { Subjek } \\
\text { Penelitian }\end{array}$ & 25 \\
\hline 2. & Skor Ideal & 100 \\
\hline 3. & Skor Tertinggi & 95 \\
\hline 4. & Skor Terendah & 55 \\
\hline 5. & Skor Rata-rata & 78,2 \\
\hline
\end{tabular}

Sumber : Olah data hasil belajar peserta didik iklus II, 2018

Berdasarkan Tabel 9 menjelaskan bahwa skor rata-rata hasil belajar peserta didik mengalami peningkatan hasil belajar dari siklus I sebelumnya.Hal ini di sebabkan karena peserta didik sudah mulai aktif dan mampu menguasai materi, walaupun masih ada beberapa peserta didik yang belum tuntas ini dikarenakan peserta didik yang kurang aktif dalam diskusi dan malas belajar. Karena ketuntasan klasikalnya sudah melebihi standar KKM yang ditetapkan dari sekolah maka peneliti tidak melanjutkan lagi ke siklus berikutnya. Selanjutnya diperoleh distribusi Frekuensi dan Persentase skor hasil belajar Matematika peserta didik pada siklus 1 yang dapat dilihat pada tabel 10 dibawah ini:

Tabel 10 Distribusi Frekuensi Dan Persentase Skor Hasil Belajar Peserta Didik kelas X SMA Negeri 9 BulukumbaPada siklus II

\begin{tabular}{llll}
\hline $\begin{array}{l}\text { Interval } \\
\text { nilai }\end{array}$ & Kategori & Frekuensi & Persentase \\
\hline $90-100$ & Sangat Tinggi & 3 & 12 \\
$80-85$ & Tinggi & 12 & 48
\end{tabular}

Fakultas Keguruan dan Imu Pendidikan Universitas Bosowa Makassar

\begin{tabular}{llll}
$70-75$ & Cukup & 7 & 28 \\
$60-65$ & Rendah & 2 & 8 \\
$0-55$ & Sangat Rendah & 1 & 4 \\
\hline Jumlah & & 32 & 100,00 \\
\hline Sumber : & Olah data hasil belajar & peserta didik \\
Siklus II, 2018 &
\end{tabular}

Berdasarkan skor rata-rata hasil belajar peserta didik yang mengalami peningkatan dari hasil belajar siklus II.Hal ini disebabkan dimana peserta didik sudah mulai aktif , mulai mampu menguasai materi yang diberikan dan saling bertukar pendapat .Sehingga peneliti tidak melanjutkan kesiklus selanjutnya

Deskripsi secara kuantitatif ketuntasan belajar Matematika peserta didik setelah memberikan tindakan dapat dilihat pada tabel 11 dibawah ini:

Tabel 11 Deskripsi Dan Persentase Skor Hasil Belajar Peserta didik pada siklus II

\begin{tabular}{|c|c|c|c|}
\hline Skor & Kategori & Frekuensi & Persentace \\
\hline $0-71$ & $\begin{array}{l}\text { Tidak } \\
\text { Tuntas }\end{array}$ & 3 & 60 \\
\hline \multirow[t]{2}{*}{$75-100$} & Tuntas & 22 & 88 \\
\hline & Jumlah & 25 & 100,00 \\
\hline
\end{tabular}

Sumber : Olah data hasil belajar peserta didik Siklus II, 2018

Dapat diketahui bahwa persentase ketuntasan belajar peserta didik setelah penerapan kooperatif tipe jigsaw mengalami peningkatan. Walaupun masih ada peserta didik yang belu tuntas sebanyak 3 orang yaitu peserta didik yang tidak serius mengikuti proses belajar mengajar dan tidak melakukan perannya dengan baik dan lebih suka bermain , Karena sebagian besar peserta didik sudah mencapai KKM maka tidak dilanjutkan lagi kesiklus berikutnya.

\section{(1) Tahap Perencanaan Siklus II}

Siklus II ini dilakukan tiga kali pertemuan,dengan waktu tempat dan jam yang sama.Adapun kompotensi dasar yang di bahas adalah KD 7.1 Mendeskripsikan 
Pengertian Manajmen,sesuai yang di paparkan di Bab III bahwa perencanaan pada siklus II sama dengan perencanaan pada siklus I ,namun pada siklus II dilakukan suatu perbaikan terhadap kendala-kendala muncul pada peserta didik yaitu tiap kelompok belum menunjukan kerjasama yang baik,masih ada beberapa siswa yang tidak mengerjakan tugas yang di berikan pendiidk,kurangnya perhatian peserta didik saat proses pembelajaran ,dan peneliti sendiri yaitu pendidik terlalu cepat menjelaskan dalam proses pembelajaran,belum mampu mengolah waktu dengan baik,sesuai dengan refleksi pada siklus I,maka peneliti dan salah satu pendidik Matematika menunjukan pada siklus II dengan memberikan pemahaman lebih kepada peserta didik mengenai model pembelajaran kooperatif tipe Jigsaw.

\section{(2) Tahap Pelaksanaan Siklus II}

Pelaksanaan tindakan siklus II berlangsung 3 kali pertemuan dengan lama waktu setiap pertemuan yaitu 3 X 45 menit proses pembelajaran berlangsung dalam tiga tahapan kegiatan yang sama dengan pelaksanaan siklus I yaitu:.(a) Kegiatan awal, (b) Kegiatan inti , (c) kegiatan akhir.

(a).Kegiatan Awal

Adapun kegiatan awal yang dilakukan di kelas X Negeri SMA Negeri 9 Bulukumba sebelum memulai pelajaran maka ketua kelas menyiapkan teman-temanya lalu berdoa sesuai dengan keyakinannya masing-masing, setelah itu pendidik lalu mengabsen siswa yang hadir satu persatu.Pendidik kemudian menjelaskan model pembelajaran Kooperatif Model Jigsaw , kemudian pendidik menginformasikan $\mathrm{KD}$, Indikator dan tujuan pembelajaran kooperatif tipe jigsaw. Selain itu pendidik juga memberikan motivasi dan pendidik juga mengingatkan kembali materi yang telah di ajarkan sebelumnya yang berkaitan dengan materi yang diajarkan.

(b.)Kegiatan Inti

Setelah Merefleksi pelaksanaan siklus I, diperoleh gambaran tindakan yang akan dilaksanakan pada siklus II sebagai perbaikan dari tindakan yang telah dilaksanakan pada siklus I .Mengingat hasil yang diperoleh pada siklus I masih tidak sesuai dengan yang diharapkan, maka tindakan yang dilakukan pada siklus II hampir sama dengan pelaksanaan tindakan siklus I hanya saja pada pelaksanaan tindakan siklus II ini terdapat perbaikan yang masih diperlukan pada siklus I.

Pada kegiatan inti proses pembelajaran , setiap kelompok terdiri dari $4-6$ siswa secara berheterogen selanjutnya tiap tim di beri materi yang berbeda-beda Tiap orang dalam tim diberi bagian materi yang ditugaskan kemudian Anggota dari tim yang berbeda yang telah mempelajari bagian sub bab yang sama bertemu dalam kelompok baru (kelompok ahli) untuk mendiskusikan sub bab mereka. Setelah selesai diskusi sebagai tim ahli, tiap anggota kembali ke kelompok asal dan bergantian mengajar dan tiap anggota lainnya mendengarkan dengan sungguh-sungguh .Selanjutnya Tiap tim ahli mempresentasekan hasil diskusi .

c.)Kegiatan Akhir

Pada kegiatan akhir pelaksanaan pembelajaran pendidik dan peserta didik bersama-sama menyimpulkan pada materi yang telah dibahas.Dan pendidik mengingatkan kembali materi yang telah diajarkan dan pada materi selanjutnya .Selanjutnya pendidik menutup kegiatan pembelajaran dengan berdoa bersama dan memberi salam.

\section{3) .Hasil Observasi Siklus II}

\section{a. Observasi}

Aktivitas peserta didik dalam pelaksanaan Siklus II pertemuan ke kedua selama proses belajar mengajar berlangsung terhadap tindakan yang dilakukan dengan menggunakan lembar observasi aktivitas peserta didik dapat dilihat pada tabel berikut ini. 
Tabel 12 Perkembangan Aktivitas Peserta Didik Kelas X SMA Negeri 9 Bulukumba pada Siklus II

\begin{tabular}{|c|c|c|c|}
\hline \multirow{2}{*}{ No } & \multirow{2}{*}{ Kegiatan } & \multicolumn{2}{|c|}{ Jumlah } \\
\hline & & $\mathrm{F}$ & $\%$ \\
\hline 1 & Kehadiran Peserta Didik & 25 & 100 \\
\hline 2. & $\begin{array}{l}\text { Peserta Didik yang aktif dalam } \\
\text { kerja kelompoknya }\end{array}$ & 25 & 100 \\
\hline 3. & $\begin{array}{l}\text { Peserta didik (kelompok ahli) } \\
\text { bertanggung jawab terhadap } \\
\text { kelompok asalnya atas materi } \\
\text { pelajaran yang telah }\end{array}$ & 20 & 80 \\
\hline & dibahas sebelumnya. & & \\
\hline 4. & $\begin{array}{l}\text { Peserta Didik yang aktif } \\
\text { mengerjakan tugas - tugasnya } \\
\text { baik secara individu maupun } \\
\text { kelompoknya. }\end{array}$ & 20 & 80 \\
\hline 5. & $\begin{array}{l}\text { Peserta Didik yang dapat } \\
\text { menyimpulkan hasil dskusi } \\
\text { pada akhir kegiatan } \\
\text { pembelajaran. }\end{array}$ & 20 & 80 \\
\hline
\end{tabular}

Tabel 12 diatas menunjukkan tentang hasil observasi mengenai aktivitas pesrta didik yang telah ditentukan untuk diamati peneliti, pada siklus II menunjukkan adanya peningkatan dari siklus I , Pada siklus II siswa sudah bisa memberikan respon yang lebih baik. Hal ini ditandai dengan siswa sudah mulai rajin mencatat indikator, banyak siswa yang aktif bertanya jawab pertanyaan, aktif dalam kerja kelomponya, hingga peserta didik dapat menyimpulkan hasil diskusi pada akhir pembelajaran.

Adapun dekripsi hasil observasi aktivitas pendidik pada siklus II selama tiga kali pertemuan dapat dilihat pada tabel 13 berikut ini

Tabel 13 Perkembangan Aktivitas Pendidik dalam Pembelajaran Matematika pada siklus II

\begin{tabular}{lll}
\hline No & Kegiatan & Kategori \\
\hline 1 & $\begin{array}{l}\text { Membangkitkan motivasi peserta } \\
\text { didik dalam mengikuti } \\
\text { mata pelajaran Matematika }\end{array}$ & $\begin{array}{l}\text { Amat } \\
\text { baik }\end{array}$ \\
& $\begin{array}{l}\text { Menyampaikan tujuan pembelajaran } \\
\text { yang ingin dicapai } \\
2\end{array}$ & Bembagi peserta didik secara \\
& heterogen sesuai & Baik \\
& dengan ketentuan model &
\end{tabular}

pembelajaran

Pendidik menyampaikan materi Amat pembelajaran sesuai dengan baik tujuan pembelajaran yang akan dicapai

5

Pendidik membagikan materi

Pendidik memberikan bimbingan

kepada peserta

Baik

didik yang membutuhkan

Pendidik mengawasi jalannya

proses belajar mengajar

Pendidik dan peserta didik sam-

8

sama menyimpulkan materi

Baik

yang telah dibahas.

Sumber : Olah Data Aktivitas Pendidik Siklus II, 2018

Berdasarkan data tabel 13 hasil observasi pada siklus II, Aktivitas pendidik dalam pelaksaan pembelajaran semakin mengalami peningkatan dalam setiap siklus.Berdasarkan penilaian aspek/indikator pertama yakni membangkitkan motivasi belajar peserta didik dalam mengikuti pelajaran Matematika dan aspek/indikator kedelapan yakni pendidik dan peserta didik sama-sama menyimpulkan materi yang telah dibahas telah mengalami peningkatan.Hal ini karena peneliti sudah bisa berinteraksi secra intensif dangan baik terhadap peserta didik dalam penerapan model pembelajaran kooperatif jigsaw.

Berdasarkan hasil pengamatan dari pengamat (rekan dari peneliti) dapat disimpulkan bahwa aktivitas pendidik berada pada kategori baik, sehingga penelitian ini diakhiri di siklus II.

\section{4).Tahap Refleksi Siklus II}

Pada pertemuan awal hingga pertemuan akhir siklus II terlihat bahwa proses belajar mengajar telah berlangsung dengan baik sesuai dengan yang diharapkan.Peserta didik sudah tidak canggung lagi menjelaskan materi kepada teman kelompoknya sehingga proses belajar mengajar berlangsung dengan baik dan aktivitas peserta didik juga dapat ditingkatkan .Peneliti lebih memperketat pengawasan kepad peserta didik yang melakukan kegiatan lain seperti ribut dan 
sebagainya.Sehingga lebih kondusif walaupun masih ada 9,00 persen atau 3 orang peserta didik yang belum tuntas.

Secara umum dapat dilakukan bahwa seluruh kegiatan pada siklsu II ini mengalami peningkatan dari siklus sebelumnya.Hal ini dapat terlihat dalam keaktifan peserta didk untuk bertanya tentang materi yang dibahas, dan keseriusan peserta didik untuk mengikuti proses belajar mengajar .Serta ketuntasan hasil belajar pun meningkat yang sebelumnya 8 yang tidak tuntas menjadi 3 orang.

\section{Pembahasan}

Pada pembahasan diuraikan bahwa berdasarkan konsep yang diuraikan peneliti pada bab II bahwa dengan menerapkan model pembelajan jigsaw dapat meningkatkan rasa tanggung jawab peserta didik terhadap pembelajaran.Pembelajaran kooperatif tipe jigsaw merupakan jenis pembelajaran yang dimana siswa belajar dalam kelompok kecil yang terdiri dari 4-6 orang secara heterogen dan bekerjasama saling ketergantungan yang positif dan bertanggungjawab atas ketuntasan bagian materi pembelajaran yang harus dipelajari dan menyampaikan materi tersebut kepada anggota kelompok yang lain.Selanjutnya akan dibahas tentang,

\section{1) Gambaran Proses Pembelajaran \\ Siswa Sebelum Penerapan Model Pembelajaran Kooperatif Tipe Jigsaw.}

Sebelum penerapan model pembelajaran kooperatif tipe jigsaw, terlebih dahulu penelitian mengamati aktivitas yang dilakukan oleh pendidik. Berdasarkan hasil pengamatan peneliti terhadap pendidik sebelum peneliti melakukan tindakan yaitu terdapat beberapa hal-hal pada aspek penjelasan materi peneliti menilai pendidik kurang melibatkan peserta didik secara aktif dalam pelajaran, selain itu proses belajar mengajar juga masih berpusat pada pendidik, Dan Pendidik hanya menggunakan metode ceramah saat proses belajar mengajar,sehingga peserta didik merasa bosan dan kurang aktif dalam berdiskusi .Jika guru memberikan kesempatan kepada siswa untuk menyampaikan pendapatnya atau kesempatan untuk bertanya tentang materi pelajaran Matematika masih banyak siswa yang malas. Pengalamanyapun dalam membawakan forum diskusi masih belum baik, siswa juga masih terbiasa dengan kebiasaan menghapal materi-materi Matematika yang ada di buku siswa jarang dilatih dalam memecahkan masalah, dan saat diberi tugas siswa lebih cenderung menunggu jawaban temannya kemudian di contek.

Dimana pendidik lebih banyak menjelaskan sedangkan peserta didik kurang diberi kesempatan untuk berdiskusi dengan temannya, peerapan kebiasaan bertanya dinilai kurang karena pendidik hanya memberikan penjelasan materi tanpa diimbangi dengan memberikan kesempatan bertanya kepada peserta didik dan tidak mengadakan tanya jawab.

Sebelum penerapan model pembelajaran kooperatif tipejigsawterlebih dahulu peneliti mengadakan pre test untuk mengetahui nilai rata-rata belajar peserta didik dengan memberikan 5 soal pada tes awal peserta didik yang hadir sebanyak 22 orang dari 25 jumlah keseluruhan peserta didik.

Dari hasil tes awal tersebut didapankan hasil bahwa masih banyak peserta didik yang mendapat nilai di bawah kriteria ketuntasan minimum (KKM). Berdasarkan dari hasil pengamatan penelitian sebelum penerapan model pembelajaran kooperattif tipejigsaw, dalam peroses pelaksanaan pembelajaran masih kurang efektif disebabkan karna masih banyak peserta didik yang tidak mencapai kreteria ketuntasan minimum (KKM), perlu diadakan perubahan dalam proses pembelajaran salah satunya adalah dengan menggunakan model pembelajaran kooperatif tipe jigsaw yang diharapakan dapat memotivasikan peserta 
didik dan meningkatkan keefektifan dalam proses belajar mengajar sehingga hasil belajar Matematika meningkat.

\section{2) Observasi aktivitas pendidik}

Pada pelaksanaan pembelajaran ini pendidik mengadakan pre tes terlebih dahulu.Melalui pre test dapat diketahui bahwa pembelajaran tersebut ternyata menjadikan peserta didik kurang antusias atau kurang semangat dalam belajar.Peserta didik cenderung pasif, bermain sendiri atau berbicara dengan temannya.Sehingga hanya mengandalkan keterangaan dari pendidik saja, dan yang terjadi peserta didik tidak mendapatkan perhatian yang lebih, merasa bosan dan bertindak semaunya sendiri.Menyikapi hasil pre tes tersebut, pada siklus I pertemuan pertama peneliti menggunakan model pembelajaran kooperatif tipe jigsaw dengan tujuan meningkatkan hasil belajar peserta didik.Pembelajaran ini diharapkan peserta didik aktif dalam proses pembelajaran, mempunyai semangat tinggi, bekerja sama, bertukar pikiran untuk menyelesaikan masalah, sehingga mendapatkan hasil yang memuskan dibandingkan dengan pembelajaran konvensioanal yang diterapkan sebelumnya oleh pendidik.

Pada siklus I , berdasarkan hasil observasi yang dilakukan bahwa masih terdapat kekurangan -kurangan yang perlu pendidik perbaiki seperti pada saat peserta didik bertanya maka pendidik menjawabnya secara singkat dan jelas supaya peserta didik lebih mudah paham dan mengerti, dan pada saat pendidik mengajukan pertanyaan kepada peserta didik agar kiranya pertanyaan jelas dan bisa dipahami peserta didik sehingga peserta didik bisa menjawabnya dengan baik dan benar, sera perlunya pengarahan pendidik kepada peserta didik dalam mengambil keputusan.

Dan pada siklus II, sesuai dengan kekurangan-kekurangan yang dilakukan pendidik pada siklus I maka pendidik melakukan perbaikan diantaranya jika ada peserta didik yang mengajukan pertanyaan kepada peserta didik secara jelas agar peserta didik mengerti dan mengarahan peserta didik dalam mengambil keputusan dan dalam hal menyimpulkan materi akhir pelajaran.

Dengan demikian hasil observasi siklus II menunjukan peningkatan aktivitas belajar pendidik meskipun masih ada kekurangan karena tidak ada satupun manusia yang sempurna.Peningkatan aktivitas pendidik dapat diamati pada lampiran 13 dan 17 mulai dari siklus I dan siklus II yang menunjukan perubahan aktivitas peserta didik melalui penerapan model pembelajaran kooperatif tipe jigsaw.

\section{3)Observasi Aktivitas Peserta Didik}

Selama berlangsung siklus I, peneliti melakukan observasi terhadap peserta didik dengan mengisi lembar observasi, dalam hal ini terlihat aktivitas peserta didik belum sepenuhnya tercapai, hal ini disebabkan karena sebagaian peserta didik belum memahami betul dengan kondisi belajar kooperatif tipe jigsaw diterapkan pendidik, sebagian peserta didik masih canggung atau belum percaya diri menjelaskan materi didepan teman kelompoknya, masih ragu dan takut untuk mengutarakan pendapat, takut salah sehingga enggan untuk mengemukakan pertanyaan saat proses belajar mengajar. Ini berarti ketercapaian indikator belum tercapai, sehingga penelitian ini harus dilanjutkan pada siklus II.

Pada Siklus II aktivitas peserta didik mulai mengalami peningkatan hal ini disebabkan karena peserta didik sudah merasa akrab dengan pendidik dan secara perlahan sudah mulai memahami model pembelajaran kooperatif tipe jigsaw.Setelah Pelaksanaan tindakan pada siklus II ,aktivitas peserta didik dari siklus I dan ke siklus II secara umum meningkat, dilihat berdasarkan beberapa aspek yang diamati, yaitu (1) Aktivitas peserta didik dalam proses belajar 
mengajar sudah mengarahkan kepembelajaran kooperatif, (2) peserta didik mampu membangun kerja sama dengan teman kelompoknya untuk memahami tugas dan tanggung jawab peranya yang diberikan pendidik. , (3) Peserta didik sudah percaya diri untuk bertanya dan menjawab pertanyaan baik dari pendidik maupun dari temantemanya serta menyimpulkan materi pembelajaran yang diberikan pendidik.Hal ini dpat dilihat dari jumlah frekuensi dan persentase dari siklus I ke siklus II sehingga dngan demikian hasil observasi terhadap aktivitas peserta didik dinyatakan berhasil.

\section{1.) Hasil Belajar Peserta Didik}

Setelah dilakukan tindakan pembelajaran pada siklus I diperoleh rata -rata hasil belajar yang masih rendah, peserta didik yang tidak tuntas dikarekan peseeta didik lebih cenderung melakukan kegiatan lain selama proses belajar mengajar berlangsung sehingga materi pembelajaran masih belum dimengerti sedangkan materi yang telah dianjurkan oleh peneliti.Perolehan ketuntasan belajar peserta didik pada siklus I, dan siklus II mengalami peningkatan dari siklus I sebesar 71,03 persen dan pada siklus II menjadi 78,81 persen.Peningkatan ketuntasan belajar peserta didik dapat disebabkan dengan adanya rasa tertarikan peserta didik dalam belajar berkelompok.

Berdasarkan hasil analisis data evaluasi berupa tes di setiap akhir siklus setelah penerapan model pembelajaran kooperatif tipe jigsaw memberikan perubahan hasil belajar yaitu terjadi peningkatan dari siklus I dan siklus II .Yakni berdasarkan hasil belajar peserta didik ditemukan bahwa pada dasarnya penggunaan model pembelajaran kooperatif tipe jigsaw memiliki potensi yang cukup baik untuk meningkatkan hasil belajar Matematika peserta didik. Hal ini ditunjukan oleh rata-rata hasil pre tes peserta didik yang dilaksanakan setelah proses pembelajaran berlangsung pada setiap siklus mengalami peningkatan.
Hasil belajar peserta didik yang telah dicapai dalam penelitian ini sudah sejalan pendapat Tsaniah dalam Nurdiansah (2008:27) yang menyatakan bahwa hasil belajar adalah terjadinya perubahan tingkah laku pada diri peserta didik, yang dapat diamati dan diukur dalam bentuk perubahan pengetahuan, sikap, dan keterampilan perubahan tersebut dapat diartikan terjadinya peningkatan dan pengembangan yang lebih baik dibandingkan dengan sebelumnya.

Untuk lebih menguatkan hasil penelitian ini.Peneliti ini sejalan dan didukung dengan penelitian yng telah dilakukan oleh Rasnawati (2013) pada peserta didik SMA Negeri I Watampone menggunakan model kooperatif jigsaw ternyata efektif digunakan dalam meningkatkan motivasi dan hasil belajar Matematika peserta didik.Hal ini juga dibuktikan oleh peneliti Nurdiana (2014) pada peserta didik kelas X Pemasaran 3 SMK Negeri Makassar menerapkan model kooperatif pembelajaran jigsaw yang menyatakan hasil penelitian dan pembahasannya dapat disimpulkan bahwa dengan menggunakan model pembelajaran koopertif tipe jigsaw dapat meningkatkan hasil belajar Matematika, hal ini dapat terlihat dari skor rata-rata tes hasil belajar dari siklus I ke siklus II meningkat serta dapat meningkatkan perhatian dan aktivitas peserta didik terhadap materi pelajaran yang diberikan pendidik .Didukung lagi penelitian yang dilakukan oleh Siti Fatimah yang masih sejalan dengan penelitian yang saya lakukan yang menyatakan bahwa model pembelajaran kooperatif tipe jigsaw sangat efektif digunakan untuk meningkatkan hasil belajar Matematika peserta didik dan dapat meningkatkan aktivitas peserta didik dalam proses pembelajaran.

Dengan melihat hasil penelitian tersebut dapat disimpulkan bahwa penerapan model pembelajaran kooperatif tipe jigsaw dapat meningkatkan aktivitas dan hasil belajar peserta didik pada mata pelajaran Matematika yang dilakukan peneliti ini dan 
juga dapat meningkatkan hasil belajar peserta didik pada mata pelajaran lain, sehingga kualitas pembelajaran kedepanya semakin meningkat, dapat mencapai kompetensi dasar yang ditentukan.Penelitian ini didukung penelitian terdahulu yang juga menggunakan penerapan model pembelajaran kooperatif tipe jigsaw dengan hasil belajar setiap siklus mengalami peningkatan. Peneliti berharap para pendidik menerapkan model pembelajaran kooperatif jigsaw dalam proses belajar mengajar sehingga peserta didik dapat aktif dalam proses belajar mengajar, mandiri dan dapat memberikan bimbingan kepada peserta didik yang mengalami kesulitan dalam memecahkan masalah.

Berdasarkan kajian pustaka dan kerangka pikir tersebut, maka hipotesis dalam penelitian ini yaitu jika model pembelajaran koopertif tipe jigsaw digunakan dalam pembelajaran Matematika maka hasil belajar peserta didik kelas Kelas X SMA Negeri 9 Bulukumba dapat meningkat. Hipotesis tersebut sejalan dengan hasil belajar peserta didik disetiap siklus mengalami peningkatan yaitu pada siklus I ketuntasan klasikal sebesar 52 ,dan pada siklus II ketuntasan klasikal meningkat menjadi 88, maka hipotesis dalam penelitian ini dapat diterima.

\section{KESIMPULAN}

Berdasarkan pembahasan hasil penelitian yang telah disajikan, maka disimpulkan bahwa:

1. Gambaran proses pemblajaran siswa sebelum penerapan model pembelajaran kooperatif tipe jigsaw adalah menggunakan metode ceramah sehingga kurang melibatkan peserta didik secara aktif dalam pembelajaran dan kurang aktif dalam berdiskusi, sehingga peserta didik didik merasa bosan karena selalu metode ceramah yang di ajarkan disaat proses belajar mengajar berlangsung, maka perlu diadakan perubahan metode belajarnya yaitu dengan menerapkan kooperatif tipe jigsaw.

2. Model pembelajaran kooperatif jigsaw dapat meningkatkan aktivitas peserta didik pada materi Himpunan pada peserta didik kelas X SMA Negeri 9 Bulukumba

3. Dengan penerapan model pembelajaran kooperatif jigsaw dapat meningkatkan hasil belajar pada materi Himpunan pada peserta didik kelas X SMA Negeri 9 Bulukumba.

\section{DAFTAR PUSTAKA}

Delianov. (2003). PerkembanganPemikiran Matematika. Jakarta: PT, Raja Grafindo Persada

Hamalik,Oemar.(2011).Kurikulum dan Pembelajaran. Jakarta : Bumi Aksara.

Imam ,Suyitna .(2013). Karya Tulis Ilmiah. Bandung: Refika Aditama.

Jalil, Jasman.(2005). Panduan Mudah Penelitian Tindakan Kelas (PTK). Jakarta: Presentasi Pustakaraya.

Jihad, Asep dan Haris, Abdul. (2013). Evaluasi Pembelajran. Multi Prossindo: Yogyakarta.

Kunandar. (2013). Penilaian Autentik (Penilaian Hasil Belajar Peserta

Didik Berdasarkan Kurikulum .(2013). PT. RajaGrafindo Persada: Jakarta.

Musfiqon. (2012). Pengembagan Media Dan Sumber Pembelajaran. Jakarta: Presentasi Pustakaraya.

Nurdiana. (2014). Penerapan Metode Pembelajaran Koopertaif Tipe Jigsaw dalam Meningkatkan Hasil Belajar Siswa pada Mata Pelajaran Kewirausahan di kelas 10 Pemasaran 3 SMK Negeri 1 Makassar.

Nurdiansah, Dia. (2008). Penerapan Model Pembelajaran Kooperatif Tipe Jigsaw Terhadap Kemampuan 
Berpikir Kritis dan Ketumtasan Hasil Belajar PadaSiswa Kelas VIII. A SMP Negeri 21 Malang. Tersedia pada Http ://Biologforum. Wordpress. com. Diakses pada tanggal 27 November 2014.

Rasnawati. (2014). Peningkatan kompetensi peserta didik tentang bank sentral dan otoritas jasa keuangan melalui model pembelajaran kooperatif tipe jigsaw pada mata pelajaran Matematika dikelas 10 sosial 1 SMA Negeri I watampone.

Rusman. (2013). Model-Model Pembelajaran. Jakarta: Raja Grafindo Persada .(2012). Belajar dan Pembelajaran Berbasis Komputer Mengembangkan

Profesionalisme guru. Bandung: Alfabet.

Sadirman. (2011).Interaksi dan Motivasi Mengajar .Jakarta :Paragrafindo Persada.

Sanjaya,Wina. (2012). Penelitian Tindakan Kelas. Jakarta: Kencana Prenada Medio Group.

Siti Fatimah. (2013). Peningkatan Hasil Belajar Peserta Didik pada Standar Kompetensi Kebijakan Pemerintah dalam Bidang Matematika melalui Penerapan Model Pembelajaran Kooperatif Tipe Jigsaw bagi Peserta Didik Kelas 10 SMA Negeri 1 Panca Lautang Kabupaten Sidenreng Rappang.

Suprianto. (2012). Modul Kegiatan Siswa Cerdas Matematika. Jakarta: Masmedia.

Wardhani, Igak dan Kuswaya Wihardit. (2009). Penelitian Tindakan Kelas. Penerbit Universitas Terbuka: Jakarta.
Wicaksono. (2014). Modul Matematika. Jakarta: Yudhistira 